\title{
COVID-19 lockdown and environmental pollution: an Indian multi-state investigation
}

\author{
Mansi Marwah · Paban K. Agrawala
}

Received: 22 July 2021 / Accepted: 14 December 2021 / Published online: 3 January 2022

(C) The Author(s), under exclusive licence to Springer Nature Switzerland AG 2022

\begin{abstract}
Originating from China, COVID-19 became the first-ever coronavirus pandemic, wreaking havoc in 218 nations. The lack of a potential treatment exacerbated by the inability of the healthcare infrastructure to contain the viral trajectory led to a worldwide lockdown. The anthropogenic halt presented an unprecedented background to quantify the effect of the anthroposphere on environmental pollution. Consequently, we analyzed the variations in the air $\left(\mathrm{PM}_{10}, \mathrm{PM}_{2.5}, \mathrm{NO}_{2}, \mathrm{SO}_{2}\right)$ and water pollutants (BOD, COD, DO, coliform) using real-time monitoring data in the majorly hit Indian metropolitan states during the lockdown in contrast to 2019 levels. The overall AQI (air quality index) de-escalated by -31 . $35 \%,-34.35 \%,-32.63 \%,-29.25 \%$ in Delhi, Tamil Nadu, West Bengal, and Karnataka, respectively, from the 2019 levels. The daily concentrations of $\mathrm{NO}_{2}, \mathrm{PM}_{2.5}$, and $\mathrm{PM}_{10}$ plunged tremendously. The exact pre-disposing factors responsible for higher COVID-19 transmission in some geographical centers remain elusive. Investigations have corroborated putative links between air pollutants and COVID19 mortalities. Therefore, we further mapped $\mathrm{PM}_{2.5}$,
\end{abstract}

M. Marwah

University School of Biotechnology, Guru Gobind Singh

Indraprastha University, Delhi, India

M. Marwah · P. K. Agrawala ( $\square)$

Institute of Nuclear Medicine and Allied Sciences, DRDO,

Brig SK Mazumdar Marg, Timarpur, Delhi 110054, India

e-mail: pkagrawal@gmail.com
$\mathrm{PM}_{10}, \mathrm{NO}_{2}$, and $\mathrm{SO}_{2}$ to co-relate with COVID-19 infectivity and mortality across the study states. Significant $(P<0.001)$ positive correlation between COVID-19 transmission was established for all pollutants with maximum co-relation with AQI followed by $\mathrm{NO}_{2}$. River Ganga water in Uttarakhand was deemed "fit for drinking" for the first time in two decades. An aggregate of $-71.94,-61.32$, and -77.94 decrease in BOD, COD, total coliform levels, and an 11.75 rise in the average DO levels from 2019 data. This study will better assist the future framework of health and environment restoration policies.

Keywords Coronavirus - SARS CoV-2 - Pandemic · Environment $\cdot$ Anthropogenic activity

\section{Introduction}

In late December 2019, an unprecedented global observation was repositioned in Wuhan city, Hubei province, China. An outbreak of a respiratory illness caused by an unidentified etiological agent with suspicious epidemiological associations to the local seafood market elicited unrest within the health authorities (Lu et al., 2020; "WHOIPneumonia of Unknown Cause-China," 2020a). Manifestations of variable severity, ranging from mild cough and fever to acute interstitial pneumonia and acute respiratory distress syndrome (ARDS), were identified as symptoms in the patients reported to the WHO China 
Country Office (Chen et al., 2020a, b; Ramanathan et al., 2020). January 7, 2020, marked the conclusion of the speculations, when the Chinese Center for Disease Control and Prevention (CDC) characterized novel Coronavirus (nCoV) as the causative virus of the pneumonia outbreak and tentatively named it nCoV2019. ("WHOINovel Coronavirus-China," 2020b; Johnson, 2020). The genomic and phylogenetic investigations unveiled striking sequence homology relating SARS-CoV-2 and bat CoV RaTG13 (96\%) more than SARS-CoV (approximately 80\%) and MERS-CoV (51\%) (Chan \& Kok, 2020; Xiantian et al., 2020; Zhou et al., 2020). To date, the bat is a potential natural reservoir of this virus (Zhou et al., 2020). Ensuing, the virus was renamed to SARS$\mathrm{CoV}-2$ by the International Committee of Taxonomy of Viruses. On 30th January, WHO reported a Public Health Emergency of National Concern (PHEIC) including 19 countries affected in the outbreak (Sohrabi et al., 2020). With the incessant evaluation of the outbreak, WHO declared COVID-19, the firstever coronavirus pandemic, given the exponential trajectory exacerbated by the lack of a potential treatment (Shen et al., 2020). Geographically, the spread circumvents 213 countries with 9,295,365 cases reported with 478,289 fatalities as of 24th June 2020.

The SARS-CoV-2 is a non-segmented positivesense RNA virus ranked under $\beta$-coronavirus, known to infect humans. Coronaviruses (CoVs) are singlestranded RNA-viruses of vertebrates infecting respiratory, gastrointestinal, hepatic, and central nervous systems of humans, livestock, birds, bat, mouse, and many other wild animals (Su et al., 2016; Weiss \& Navas-Martin, 2005). Coronaviruses are not unheard of. Hitherto, human-susceptibility of $6 \mathrm{CoVs}$ has been recognized, four with mild pathogenicity and minor symptom comparable to common cold while the other two who are gravely fatal (Kin et al., 2015). Studies assessed the basic reproduction number (R0) of SARS-CoV-2 to be around 2.2, or even more (ranging from 1.4 to 6.5) (Riou \& Althaus, 2020; WHO, 2020).

Historically, the twenty-first century saw the sporadic emergence of two coronavirus outbreaks: the severe acute respiratory syndrome (SARS-CoV) epidemic to China in December 2002 with a fatality rate $9.3 \%$ and the Middle East respiratory syndrome (MERS-CoV) endemic to UAE in June 2012, with a mortality of 23.1\% (Zulma et al., 2015; Song et al., 2019; Graham et al., 2013; Minhas, 2015; Su et al., 2015; Hui et al., 2018). These rates vary with the COVID-19 CFR (case fatality rate) of $2.6 \%$ (WHO, 2020; World Health Organization, 2020c). Despite the lower mortality rate, the community spread (human-tohuman transmission) is a significant contributor to the frenzy of fear and worldwide panic (Chan et al., 2020; Li et al., 2020). In the succeeding Tatem and Lai's model (Chen et al., 2020a, b; Lai et al., 2020) assessing non-pharmaceutical interventions amidst the Wuhan outbreak, governments across the globe prioritized principally early detection and isolation, ensued by limitations on population movement. The promising results of mass quarantine in China to dam the tidal corona wave led to nationwide lockdown or geographic quarantines across the globe. The world's biggest economies like China, India, USA, Russia, France, Italy, UK, and Spain suspended public gatherings (leisure, religious, political, business, sports, educational), international and domestic travel, public transport and non-essential industries at different time dots of the pandemic with varying strictness (Lau et al., 2020; Pepe et al., 2020; Pulla, 2020). The duration varied from months to a few weeks. Albeit, this dark cloud definitely has silver lining of its own. Social lockdown not only reduced inter-personal interaction but a significant human-environment interaction de-escalated including the relentless anthropogenic exploitation of the entire biosphere. This resulted in some unexpected prosperity of the Earth. A relative drop as drastic as global carbon dioxide emissions in 2020 has not been reported since World War II (Rutz et al., 2020). The $\mathrm{NO}_{2}$ emission drop during the lockdown has been unparalleled. The decline in the noise of human activities is seen as a boon for geoscientists, studying the earthquakes and other seismic parameters. This work aims to measure the declines in the environmental pollutants (air and water) as catalyzed by the lockdown in the urban centers of India like Delhi, Karnataka, West Bengal, and Tamil Nadu.

Albeit global efforts, the exact predisposing factors contributing to higher incidences and death in certain geographical regions remain obscure. Individuals with comorbidities, including cardiovascular, chronic respiratory infirmities, diabetes, and cancer are at greater risk of exacerbated clinical severity and death (Verity et al., 2020). Several studies have established augmented respiratory and cardiovascular toxicity 
upon chronic exposure to unhealthy levels of air pollutants (WHO, 2018; Faustini et al., 2014). Hence, some countries have hypothesized and demonstrated that air pollutants correlate with COVID-19 transmission trajectory and mortality rate (Brandt et al., 2020; Shakoor et al., 2020; Conticini et al., 2020).

The expeditious augmentation of anthropogenic activities, including automobiles, industrial processes, and mining, has led to burgeoning the pollution mortality burden (Sharma et al., 2020). Continued exposure to transportation pollutants like nitrogen oxides can provoke inflammation and oxidative tension, likely to incite and exacerbate infirmities such as childhood asthma, lung cancers, chronic obstructive pulmonary disease, and diabetes (Guarnieri \& Balmes, 2014; WHO, 2018; Achakulwisut et al., 2019; Strak et al., 2017). This has bolstered the hypothesis examination of a relationship between air pollution and COVID19 (Conticini et al., 2020; Wu et al., 2020). Therefore, we further aimed to explore the relationship between air pollution exposure and COVID-19 mortality and infectivity in the major urban states of India.

\section{Methodology}

A literature survey was conducted using different databases including PubMed, Science Direct, Google Scholar, N-LIST (National Library and Information Services), and World Health Organization.

The level of air pollutants was analyzed using the real time monitoring data of Central Pollution Control Board (CPCB), India, for the states of Delhi, Tamil Nadu, Karnataka, and West Bengal. Delhi, Karnataka, Tamil Nadu, and West Bengal were chosen as they house the major metropolitan cities of India and were worst hit by the pandemic. The name and number of stations were chosen according to the full availability of data for the required period (Table 1). The filtering of air pollutants was done to $\mathrm{NO}_{2}, \mathrm{PM}_{2.5}$, and $\mathrm{PM}_{10}$ and $\mathrm{SO}_{2}$. In this study, daily $24 \mathrm{~h}$ concentrations of pollutants, nitrogen-dioxide $\left(\mathrm{NO}_{2}\right)$, sulfur dioxide $\left(\mathrm{SO}_{2}\right), \mathrm{PM}_{2.5}$, and $\mathrm{PM}_{10}$ were measured. The $24 \mathrm{~h}$ average concentration of AQI was also collected and compared to the 2019 mean levels. The time-period was divided into pre-lockdown (1st March 2020-22nd March 2020), lockdown (22nd March-1st June 2020) and unlock 1.0 (1st June-14th June 2020).
Table 1 Names of stations selected for the study in four states of India

\begin{tabular}{|c|c|c|}
\hline State & $\begin{array}{l}\text { Number of } \\
\text { stations }\end{array}$ & Name of station \\
\hline Delhi & 8 & $\begin{array}{l}\text { Dwarka Sector } 8 \\
\text { Wazirpur } \\
\text { Jahangirpuri } \\
\text { Shadipur } \\
\text { ITO } \\
\text { Anand Vihar } \\
\text { Airport } \\
\text { Jwaharlal Nehru Stadium }\end{array}$ \\
\hline Karnataka & 9 & $\begin{array}{l}\text { Bapuji Nagar } \\
\text { BTM } \\
\text { BWSSB } \\
\text { City Railway Station } \\
\text { Hebbal } \\
\text { Honegowda } \\
\text { Jayan Nagar } \\
\text { Peenya } \\
\text { Shivamoga } \\
\text { Silk Board }\end{array}$ \\
\hline West Bengal & 8 & $\begin{array}{l}\text { Assonsal } \\
\text { Ballygunge } \\
\text { Fort William } \\
\text { Howrah } \\
\text { Howrah Belurmath } \\
\text { Padmapukar } \\
\text { Ward-32 Bapupara } \\
\text { Victoria }\end{array}$ \\
\hline Tamil Nadu & 5 & $\begin{array}{l}\text { Alandpur bus depot } \\
\text { Coimbatore } \\
\text { Manali } \\
\text { Manali village } \\
\text { Vellacherry }\end{array}$ \\
\hline
\end{tabular}

The mortality rate per million population and infectivity rate per million populations were retrieved through Institute for Health Metrics and Evaluation (IHME), Washington. To find the association between COVID-19 and environmental pollutants and COVID-19 mortality and infectivity rate, the data was analyzed for 1st April 2020 to 14th June 2020. Correlation analysis between AQI, $\mathrm{NO}_{2}$, and $\mathrm{PM}_{2.5}$ and $\mathrm{SO}_{2}$ levels was done using Pearson's co-efficient. Spearman and Kendell correlation co-efficient were also calculated. Two-tailed ANOVA test was performed in calculating the $p$-value. 
For the analysis of the water pollutants, the data from Uttarakhand Pollution Control Board (UPCB) was analyzed for 11 stations. The mean 2019 and 2020 levels were analyzed for the month of March and April 2020 in contrast to 2019 mean levels.

The relevant studies were explored using keywords: COVID-19, environment, positive impact, seismic noise, GHG, air pollution, telemedicine, Ganga, underwater noise, water pollution, and India.

\section{Results and discussion}

\section{Air pollution and COVID -19}

Stringent lockdown measures declared to stem the escalating virus spread resulted in a drastic decrease in the levels of air pollutants. The combined effects of a substantial reduction in surface transport, aviation, and electricity consumption lead to dramatic drops in daily global $\mathrm{CO}_{2}$ emissions. The following de-escalated by $-17 \%$ ( -11 to $-25 \%$ for $\pm 1 \sigma$ ) by early April 2020 in contrast with the calculated average of 2019. This drop shows a direct dependence on the duration of the lockdown, with a minimum approximation of $4 \%$ if midJune marks the return of pre-pandemic carbon-intensive cycles and a skyrocketing 7\% if 2020 witnesses some restrictions throughout the year (Le Quéré et al., 2020). The decline rates could translate into limiting climate change to a $1.5{ }^{\circ} \mathrm{C}$ warming if the rates of decline remain maintained (United Nations Environment Program, 2019; Wigley et al., 1981). At this paradigm, government policies and economic incentives post crisis might determine the global $\mathrm{CO}_{2}$ emission trajectories for decades to come.

Air pollution levels over Northern India plummeted to a marveling 20-year-low amidst the lockdown period (Gautam, 2020). Of the 103 cities in India, 21 are amongst the world's 30 most polluted cities, which recorded improved air quality throughout the lockdown (Bedi et al., 2020; Ginzburg et al., 2020; IQAir, 2019). Our results from the real time monitoring data from CPCB of the air pollutants in the states' housing the 4 major metropolitan cities in India, namely, Delhi, Karnataka, Tamil Nadu, and West Bengal demonstrated noteworthy drops of -31 . $3513 \%,-34.3513 \%,-32.6367 \%$, and $-29.2515 \%$, respectively, in contrast to mean 2019 AQI averages (Fig. 1a-d). Amongst the four states, Delhi observed the highest AQI levels (Fig. 1e).
Our results from the interstate analysis of the real time monitoring air pollutant data from all the available stations in the CPCB database reveal an average concentration de-escalation of $\mathrm{PM}_{2.5}$ level by $-52.83 \%,-46.82 \%,-44.68 \%$, and $-37.69 \%$ in Delhi, Karnataka, Tamil Nadu, and West Bengal (Fig. 2). $\mathrm{PM}_{2.5}$ and $\mathrm{PM}_{10}$ can potentially damage the lungs, heart, and brain and have exacerbated the mortalities attributed to air pollution. The percentage decrease of $\mathrm{PM}_{10}$ in all the four states was drastic, with West Bengal showing the greatest plummets (Fig. 2c). This can be attributed to the fact that the monitored stations are located within the industrial hubs of West Bengal. Preliminary investigations also indicate increased COVID-19 mortality rates with greater exposure to air pollutants, mainly $\mathrm{PM}_{2.5}$ (Wu et al., 2020). Further investigation burgeoning further insights of this relationship is required in the Indian subcontinent. Furthermore, we observed tremendous $\mathrm{NO}_{2}$ declines in daily averages by $-40.5,-46.69-32.69$, and-58.01 in Delhi, Karnataka, Tamil Nadu, and West Bengal (Fig. 2d). Our results are coherent with other studies (Vadrevu et al., 2020). The abated air pollution levels may translate into reducing the burden of air pollution mortalities, weighing down a load of one quarter of all adult deaths from cardiac disorders, one quarter from stroke, $43 \%$ from chronic obstructive pulmonary disease, and 29\% from lung cancer (WHO, 2018). Air pollution triggers the premature deaths of 7 million people globally (WHO, 2019).

The TROPOspheric Monitoring Instrument (TROPOMI) and Ozone Monitoring Instrument (OMI) calculations quantified an unprecedented $-40 \%$ drop in $\mathrm{NO}_{2}$ levels over Chinese cities during the lockdown. Wuhan, the epicenter of the outbreak, saw a-60\% drop, hitting the rock-bottom in the last 15 years (Bauwens et al., 2020). The European cities witnessed parallel NO2 decline of $-27 \%$ and $-25 \%$ between the two instruments. Milan (Italy) showed a maximum de-escalation of $-38 \%$, outranking the consolidated reduction of $-20 \%$ shown by emission regulations and the European economic recession spanning the 2004-2010 period (Bauwens et al., 2020; Castellanos \& Boersma, 2012). Studies have attributed accelerated diffusion of COVID-19 to local air pollution levels in parts of Europe, especially $\mathrm{NO}_{2}$ and ozone (Coccia, 2020). Ogen revealed $\mathrm{NO}_{2}$ exposure as the leading contributor to COVID-19 fatalities (Ogen, 


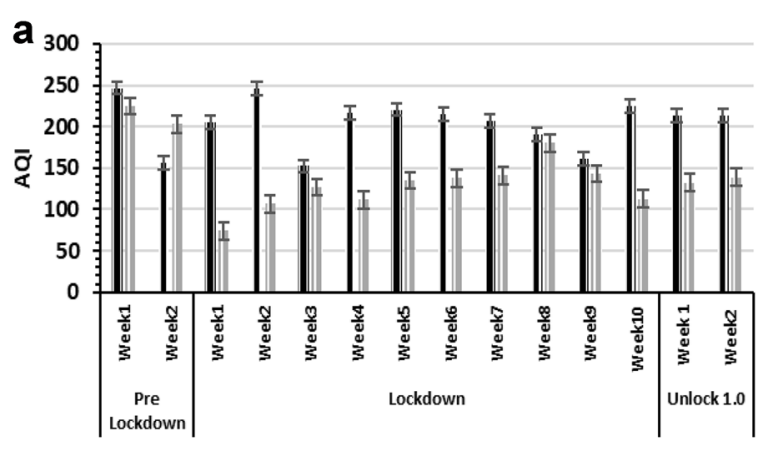

|II Delhi 2019 || Delhi 2020

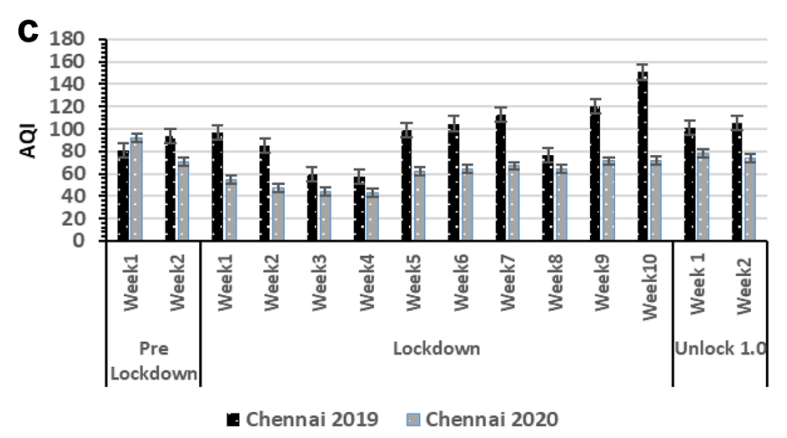

- Chennai 2019 Chennai 2020

e 25

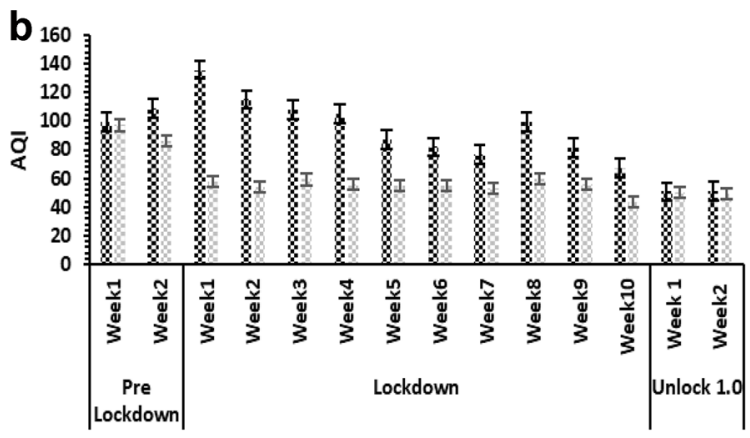

\& Bengaluru 2019 \& Bengaluru 2020

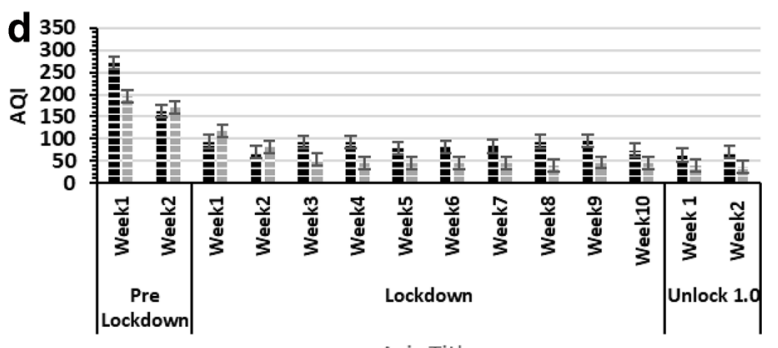

Axis Title

E Kolkata 2019 Eolkata 2020

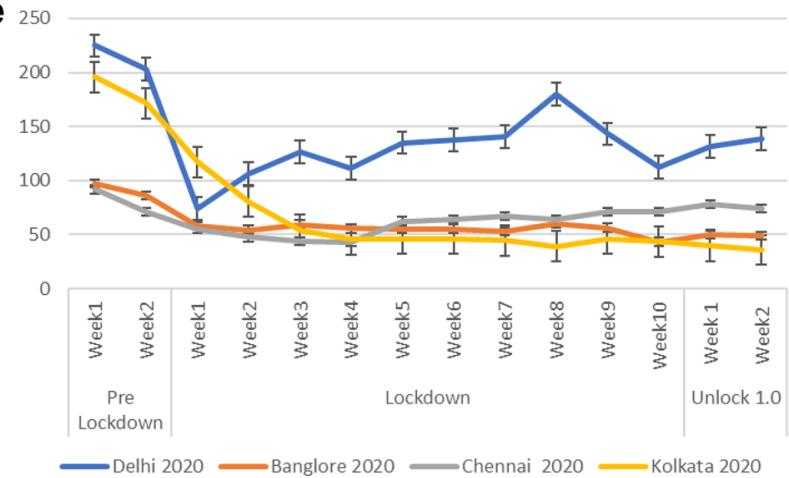

Fig. 1 Effect of lockdown on air pollution. a The weekly average AQI levels of Delhi during the period of 7 th March 2020-14th June 2020 vs 7th March 2019-14th June 2020. b The weekly average AQI levels of Chennai during the period of 7th March 2020-14th June 2020 vs 7th March 2019-14th June 2020. c The weekly average AQI levels of Bengaluru

2020). Moreover, $\mathrm{NO}_{2}$ is the single leading source of childhood asthma in urban areas across the globe (Achakulwisut et al., 2019).

The USA also saw a decrease of $-24 \%--28 \%$ in $\mathrm{NO}_{2}$ level. Fuel combustion, being the chief anthropogenic cause of NOx, attributes to approximately $65 \%$ of total NOx emission globally. Therefore, the key driver of the plummet reduced traffic levels. In China during the period of 7th March 2020-14th June 2020 vs 7th March 2019-14th June 2020. d The weekly average AQI levels of Kolkata during the period of 7th March 2020-14th June 2020 vs 7th March 2019-14th June 2020. e The intercity comparsion of AQI levels of the 4 megacities: Delhi, Bengaluru, Chennai, and Kolkata

and the USA, road traffic drops of $-81 \%$ and $-45 \%$ were observed (Schuman, 2020). With surface transport reckoning a significant portion of the slide in emissions, the surface transportation sector could be an invaluable subject of policy changes. Compliant to social distancing, mandating active travel policies could help to condense $\mathrm{CO}_{2}$ emissions (Kissler et al., 2020). The de-escalated pollution levels is a reprieve 
a
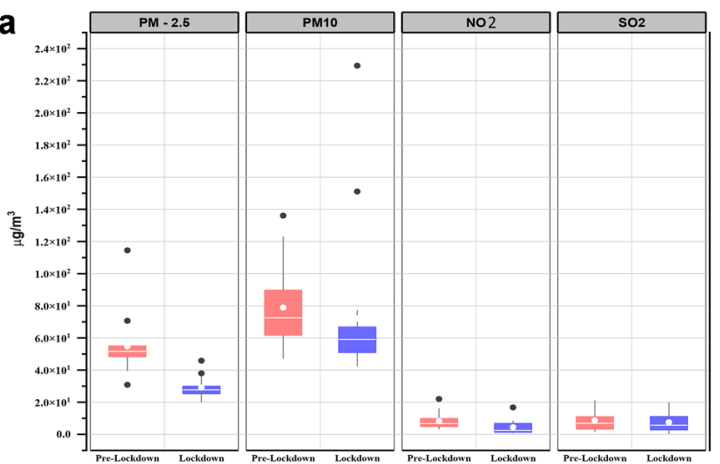

C

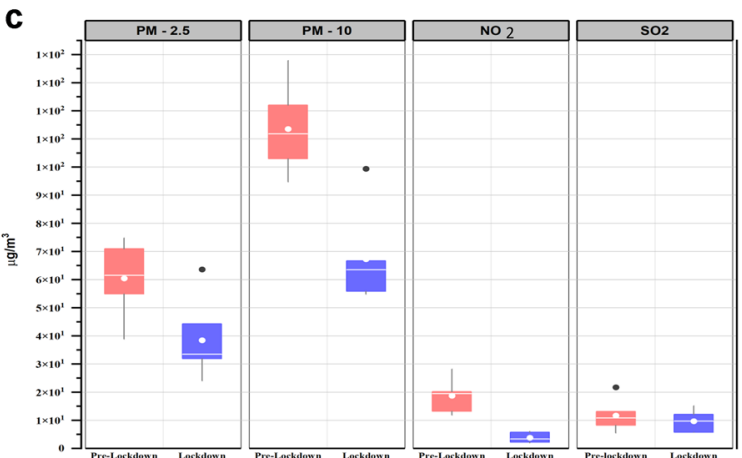

Fig. 2 Effect of lockdown on air pollutants. a Pre-lockdown vs lockdown daily averages of $\mathrm{PM}_{2.5}, \mathrm{PM}_{10}, \mathrm{NO}_{2}$, and $\mathrm{SO}_{2}$ from the real-time monitoring data from CPCB in Delhi. b Pre-lockdown vs lockdown daily averages of $\mathrm{PM}_{2.5}, \mathrm{PM}_{10}, \mathrm{NO}_{2}$, and $\mathrm{SO}_{2}$ from the real-time monitoring data from CPCB in Kar-

for $90 \%$ population of the world that breathes polluted air, as according to the WHO (World Health Organization, 2018). Being able to measure the effect of every anthropogenic activity profoundly on the air pollution levels on one hand, the significant results of the applied lockdown will form the basis to reform the world pollution policies to minimize the concentration of air pollutants on a long-term basis.

The differential air pollutant concentrations might play a pivotal role in not only the transmission of
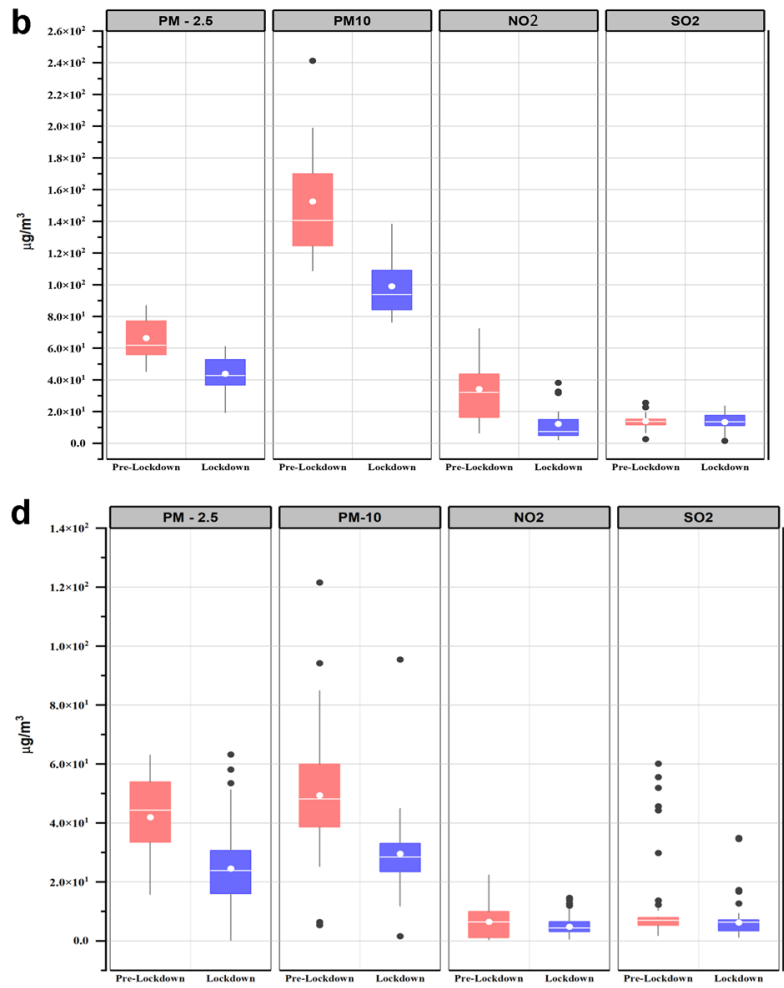

nataka. c Pre-lockdown vs lockdown daily averages of $\mathrm{PM}_{2.5}$, $\mathrm{PM}_{10}, \mathrm{NO}_{2}$, and $\mathrm{SO}_{2}$ from the real-time monitoring data from CPCB in West Bengal. d Pre-lockdown vs lockdown daily averages of $\mathrm{PM}_{2.5}, \mathrm{PM}_{10}, \mathrm{NO}_{2}$, and $\mathrm{SO}_{2}$ from the real-time monitoring data from CPCB in Tamil Nadu

COVID-19 but might also be one of the reasons responsible for the variations in the viral trajectory of different states. Table 2 displays the empirical results of the association between COVID-19 (infectivity and mortality) and AQI across the four major states of India. Delhi and Tamil Nadu showed strong positive correlation ( $p$-value $<0.005)$, whereas West Bengal and Karnataka showed weak negative correlation. This might be attributable to higher mean levels of AQI in Tamil Nadu and Delhi than in other study
Table 2 Pearson co-efficent $\mathrm{b} / \mathrm{w}$ AQI and infectivity and mortality rates
Period: 1st April 2020 to 14th June 2020

\begin{tabular}{lllll}
\hline & \multicolumn{2}{l}{ Pearson co-efficient } & & \\
& Delhi & Tamil Nadu & West Bengal & Karnataka \\
Covid-19 infectivity rate & 0.64909 & 0.740331 & -0.027411 & -0.32368 \\
Covid-19 mortality rate & 0.625658 & 0.70656 & -0.19726 & -0.21229 \\
$\boldsymbol{P}$-value & $2.417 \mathrm{E}-05$ & $1.69 \mathrm{E}-12$ & 0.089823 & 0.000149 \\
\hline
\end{tabular}


states. These two areas recorded the highest weekly average concentration $\left(\mu \mathrm{g} / \mathrm{m}^{3}\right)$ of nitrogen dioxides.

Furthermore, Table 3 represents the different correlation co-efficient for COVID-19 infectivity and mortality for all the air pollutants $\left(\mathrm{NO}_{2}, \mathrm{PM}_{10}, \mathrm{SO}_{2}\right.$, $\mathrm{PM}_{2.5}$ ) and for all the Indian study states combined. Our findings show that COVID-19 mortality and infectivity show significantly positive correlations with all the air pollutants in all the three correlation co-efficients. AQI showed the highest correlation with mortality and infectivity rate in all the three correlation co-efficient. $\mathrm{PM}_{2.5}, \mathrm{PM}_{10}$, and $\mathrm{NO}_{2}$ showed positive association with the COVID-19 transmission in Pearson's co-efficient. While in Spearman's and Kendal's co-efficient, we found that $\mathrm{NO}_{2}$ showed strong positive association and $\mathrm{PM}{ }_{2.5}$ and $\mathrm{PM}_{10}$ showed weak positive correlations.

A combined correlation plot for the four states indicated significant $(p<0.001)$ positive correlations with all the five air quality indicators. The highest Pearson's co-efficient was observed for AQI (0.48) while the least was for $\mathrm{SO}_{2}$ (Fig. 3).

Bilal et al. (2020) analyzed and reported that $\mathrm{O}_{3}$, $\mathrm{PM}_{2.5}$, and $\mathrm{NO}_{2}$ were positively associated with

Table 3 Correlation co-efficents b/w daily average concentrations of AQI, $\mathrm{PM}_{10}, \mathrm{PM}_{2.5}, \mathrm{NO}_{2}, \mathrm{SO}_{2}$ and COVID-19 infectivty and mortality rates

\begin{tabular}{lcl}
\hline Pollutants & Mortality rate & Infectivity rate \\
\hline Pearson's correlation co-efficient & \\
AQI & 0.49 & 0.58 \\
NO2 & 0.33 & 0.4 \\
PM-10 & 0.39 & 0.43 \\
PM-2.5 & 0.40 & 0.44 \\
SO2 & 0.35 & 0.4 \\
Spearman correlation co-efficient & \\
AQI & 0.41 & 0.47 \\
NO2 & 0.55 & 0.58 \\
PM-10 & 0.26 & 0.23 \\
PM-2.5 & 0.28 & 0.24 \\
SO2 & 0.2 & 0.18 \\
Kendal correlation co-efficient & \\
AQI & 0.29 & 0.32 \\
NO2 & 0.38 & 0.41 \\
PM-10 & 0.17 & 0.14 \\
PM-2.5 & 0.17 & 0.14 \\
SO2 & 0.1 & 0.080 \\
\hline
\end{tabular}

COVID-19 cases and deaths. An investigation from Thailand purported that $\mathrm{CO}, \mathrm{PM}_{10}, \mathrm{NO}_{2}, \mathrm{O}_{3}$, and $\mathrm{SO}_{2}$ significantly increased the risk of respiratory diseases (Phosri et al., 2019). Travaglio et al. (2021) showed significant spatial correlation between $\mathrm{NO}_{2}$ and the COVID-19 deaths and infectivity in England. The study further corroborated $\mathrm{PM}_{2.5}$ as a major contributor to the COVID-19 trajectory in England by establishing that a $1-\mathrm{m}^{3}$ increase in long-term $\mathrm{PM}_{2.5}$ was responsible for $12 \%$ increase in COVID-19 cases. An investigation also purported that the severity of COVID-19 outbreaks in Northern Italy could be due to the PM concentrations, one of the highest in Europe (Setti et al., 2020). In Italy, Bernardini et al. (2020) also demonstrated the putative links between air pollutants $\left(\mathrm{CO}, \mathrm{NO}_{2}, \mathrm{O}_{3}\right.$, and $\left.\mathrm{PM}\right)$ and COVID19 and reported significant positive correlation. These evidences bolster our investigation and suggest that COVID-19 transmission and severity might spread through environmental pollutants.

Our study may have certain limitations. Primarily, we investigated the association between COVID-19 mortality/infection and air pollutants, but our findings are not a complete representation due to the inclusion of only four Indian states. Therefore, studies which could include all the Indian states might be beneficial. Future studies should address these limitations.

Noise pollution and COVID-19

\section{Seismic noise: the golden silence}

Seismic noise is the vibration in the Earth's crust caused by a multitude of natural and anthropogenic activities (Brune \& Oliver, 1959). With the pandemic in force, the anthropic noise, usually detected as a near-continuous signal or background noise at the seismometers, came to a halt (Boese et al., 2015; McNamara \& Buland, 2004). Seismometers recorded sharp declines in the seismic noise. Royal Observatory in Belgium observed $30-50 \%$ drops in ambient seismic noise from the levels at the beginning of the year (Mallapaty, 2020). In Northern Italy, an almost 50\% energy minimization in the frequency spectrum of 1-10 Hz was reported (Poli et al., 2020). China saw a 4-12 dB attenuation in the $1-8 \mathrm{~Hz}$ frequency band (Xiao et al., 2020). Countries like the USA, Spain, and Mexico witnessed similar slopes. This unprecedented phenomenon on a global scale 


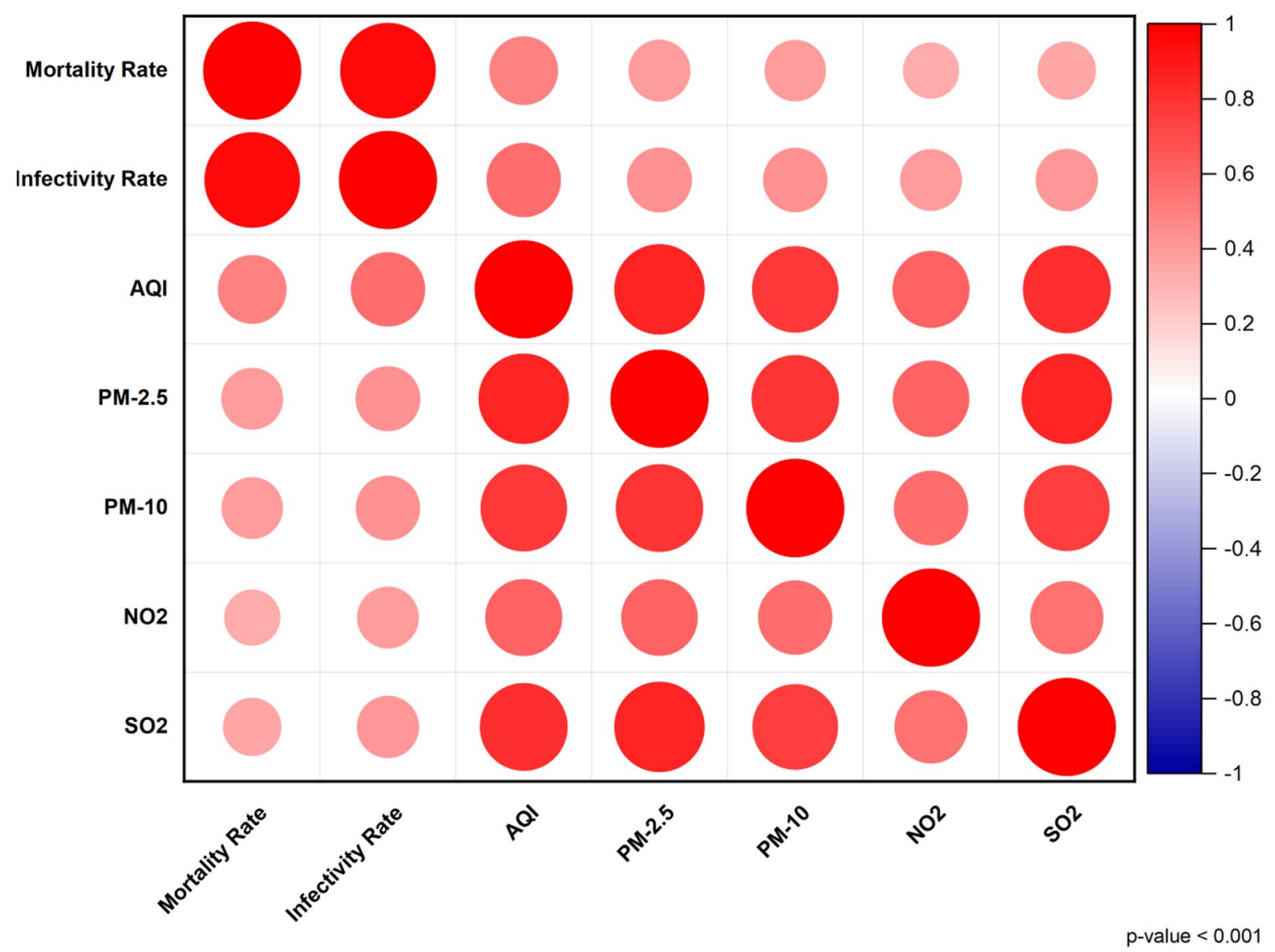

Fig. 3 The correlation plot between COVID-19 infectivity, mortality rates, and major air pollutants

was an extraordinary opportunity to analyze the anthropogenic seismic network elaborately, which in history was far-fetched. During the interlude of March to May 2020, Lecocq et al. reported a $50 \%$ plunge in the global median hiFSN (Lecocq et al., 2020). The data indicates the most extensive and coherent declines in seismic noise documented in the chronicles. A significant correlation between alterations in seismic noise and population mobility emphasizes seismology offering real-time monitoring for human activity patterns (Lecocq et al., 2020; Lindsey et al., 2020), moreover, offering fewer privacy concerns over mobility data tracking.

A stunning $80 \%$ plummet in the seismic plots of some cities in Nepal was published (https:// www.nationalge ographic.com/science/2020/04/ coronavirus-is-quieting-the-world-seismic-datashows). These declines turned out unequivocally significant to geoscientist. In urban centers, the anthropic signal degrades the capacity of seismometers to identify transient signals from earthquakes and volcanoes, hindering their ability to predict geological hazards (Ashenden et al., 2011). This detection predicament is graver in populous areas, where the spectrum of anthropogenic noise interferes with earthquake signal spectra. The heightened stillness that elicited quarantine measures is crucial for seismologists to study fainter earthquakes that slipped past their instruments previously (Ross et al., 2019). Accurate detection of fainter earthquakes in the high-risk earthquake zones like Los Angeles will be a boon. Detection of tremors from potential volcanic unrest that was concealed by anthropogenic noise could be detected (Boese et al., 2015). The lately identified signals could form the potential distinct templates for locating comparable waveforms 
in noisier data amidst the pre- and post lockdown period. Better detection and understanding of ocean waves and volcanic eruptions could unlock research doors.

The reduced seismic graph gives unparalleled clarity on the coherent contribution of human behavior on seismic noise and Earth's crust. With the exponential increase in population, exposure to potential, natural, and induced geohazards will develop (Mccall et al., 1998). The swift urban wave will undulate high tides of anthropogenic noise, complicating seismic monitoring efforts. Therefore, the opportunity that the pandemic presents to characterize anthropogenic noise will facilitate its minimization in the future, enabling seismic signatures of harmful subsurface jeopardizes with greater accuracy.

\section{Noise pollution and health consequences}

"One day man will have to fight noise as fiercely as cholera and pest" are the famous words of Robert Koch. Long-term and short-term exposure to elevated levels of environmental noise is concerned with diabetes, poor sleep, anxiety, noise-induced hearing loss (NIHL), and heart diseases (Clark and Paunovic, 2018; van Kempen et al., 2018). According to a recent study in the European Heart Journal, a 34\% augmentation in risk for heart attack, heightened aerial inflammation, and stroke was associated with every 5 decibels increase in environmental noise (Osborne et al., 2020). Clutching 58 million people worldwide, one of the most predominant irreversible occupational hazards is NIHL (Heiberger \& Holland, 2015). About 290 million people in Europe alone are exposed to unhealthy levels of noise. While the world stayed indoors, drastic reductions in noise pollution were recorded. According to CPCB, Delhi witnessed drastic drops as low as $50 \mathrm{db}$ (A) in contrast to unprecedented high records of $100 \mathrm{db}$ (A) in the pre-lockdown period (Ibrar \& Gandhiok, 2020). Indian metropolitan cities observed an overall drop of $15-25 \%$. The reduced trends were noted in parts of Europe and USA as a period of seismic silence (Asensio et al., 2020; Basu et al., 2020; El País, 2020; Smith et al., 2020). The reduced burden of vehicular road was the fundamental contributor of the same, indicating the need for sustainable stringent transportation strategies in order to meet the WHO permissible levels. The amount of reduction can be extrapolated to determine the amount of behavioral shifts necessary to regulate permissible levels.

\section{Under water noise pollution: the paradigm of stress} to marine life by anthropogenic activities

Although imperceptible, underwater noise (UWN) pollution is an emerging environmental concern that will undulate through oceans with an expected $87-102 \%$ escalation by 2030 . The mounting tide of human maritime activities, with shipping as the ambassador, is accountable for this acoustic pollution (Kaplan \& Solomon, 2016).

Following the global lockdown, oceans witnessed a breach from the clatter of anthropogenic activities. A new study using near real-time ocean noise sensing observatories (Venus and Neptune) declared large negative trends in the first quarter of 2020. A $1.5-\mathrm{dB}$ drop in year-over-year weekly noise, both in the Inland waters and deep ocean of Canada's Pacific West coast at low frequencies $(100 \mathrm{~Hz})$ was reported (Thomson \& Barclay, 2020). This is roughly a $25 \%$ decrease in power. Reduced ship traffic due to a $14 \%$ decline in import-export at the coast is the key contributor to the result.

Marine fauna relying on acoustic signaling as one of the most efficient ways of communication for their vital biological processes benefited the most. The significant overlap between the low-frequency spectrum of shipping traffic noise and acoustic signals (2-200 Hz) interferes with this communication leading to habitat displacement, behavioral changes, and altered foraging patterns in the organisms (Clark et al., 2009; Nowacek et al., 2007; Tyack, 2008). A study stated the reduction of stress-related fecal hormone metabolites in whales following the decline in the underwater noise after the 9/11 episode (Rolland et al., 2012). This decline could be a reprieve to whales, crustaceans, and marine mammals communicating in the same frequency spectra. The data is indicative of an oceanographic noise environment closer to that of 150 years ago. The scientists across the globe foresee the hushed oceans as a once in a lifetime opportunity to listen to the marine fauna and study the effects of anthropogenic induced noise on the same and in a profound way. 
Coronavirus: a vaccine for the Indian waters

While 1.3 billion people adhered to community quarantine to curb the spread of the COVID-19 outbreak, at Haridwar, Ganga's water quality was ranked as fit for drinking (class A) by UPCB (Dutta et al., 2020). The analysis of the water characteristics of 11 station in Uttrakhand from the UPCB database revealed a tremendous $-71.94570136,-61.32596685$, and -77.94676806 decrease in BOD and COD, Total coliform levels and an 11.75213675 raise in the average DO levels in contrast to 2019 levels (Fig. 4). The industrial shutdown and improved air quality could be the main contributors to these noteworthy improvements.

Hitherto, since the foundation of Uttrakhand, this extraordinary phenomenon was unheard-of. CPCB's real-time water quality monitoring system (RTWQMS) recorded suitability for bathing (class B) for an enormous $75 \%$ stations, installed at the chief channels of the Ganga River (Singhal, 2020). Former reports enunciated that most of the monitoring stations recorded water quality inappropriate for bathing (Kamboj \& Kamboj, 2019). The research also affirms unprecedented declines in fecal coliform
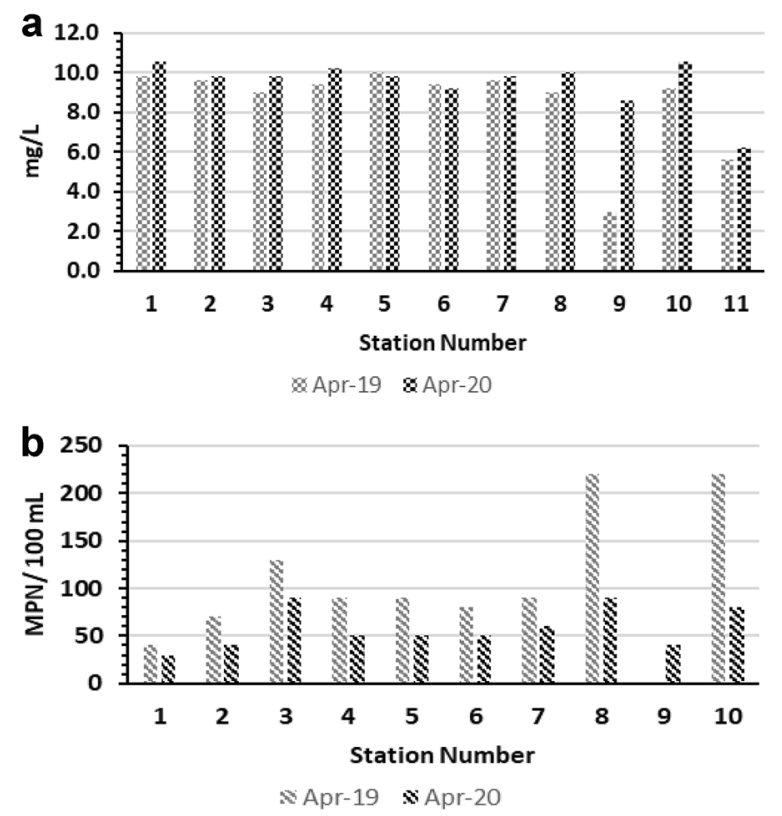

Fig. 4 Effect of lockdown on water pollution. a 2019 vs 2020 monthly averages comparison of DO for 11 stations in Uttrakhand. b 2019 vs 2020 monthly averages comparison of total coliform levels for 11 stations in Uttrakhand. c 2019 vs 2020 and nitrate concentration, increase in DO (3-20\%) (Dutta et al., 2020). With 4 million annual deaths attributed to water and sanitation in India (Francis, 2011), the health expenses credited to water pollution in India are INR 470-610 billion (US \$6.7-8.7 billion) each annum (World Bank, 2013). The improved hallmarks might translate into a meaningful reduction of overall risk of water-related mortalities and infirmities, which are a direct consequence of unhealthy water characteristics and globally might qualify the burden of 1.5 million children under the age of five, who succumb to water-related diseases, and 485,000 annual diarrheal deaths (UNICEF, 2006). The steep decline in the industrial discharge of untreated wastewater coupled with increased rains was the ambassador of this significant improvement, as the discharge of domestic sewerage was unaltered. This emphasizes the influential impact of untreated or semi-treated commercial-industrial wastewater on water quality, which is about 650 million liters per day (Trivedi, 2010). The optical depth analysis of the Indo-Gangetic Plains by NASA highlighted a 20 -year-plumet in aerosol. The assessment gives the government regulators unequivocal proof to stringent

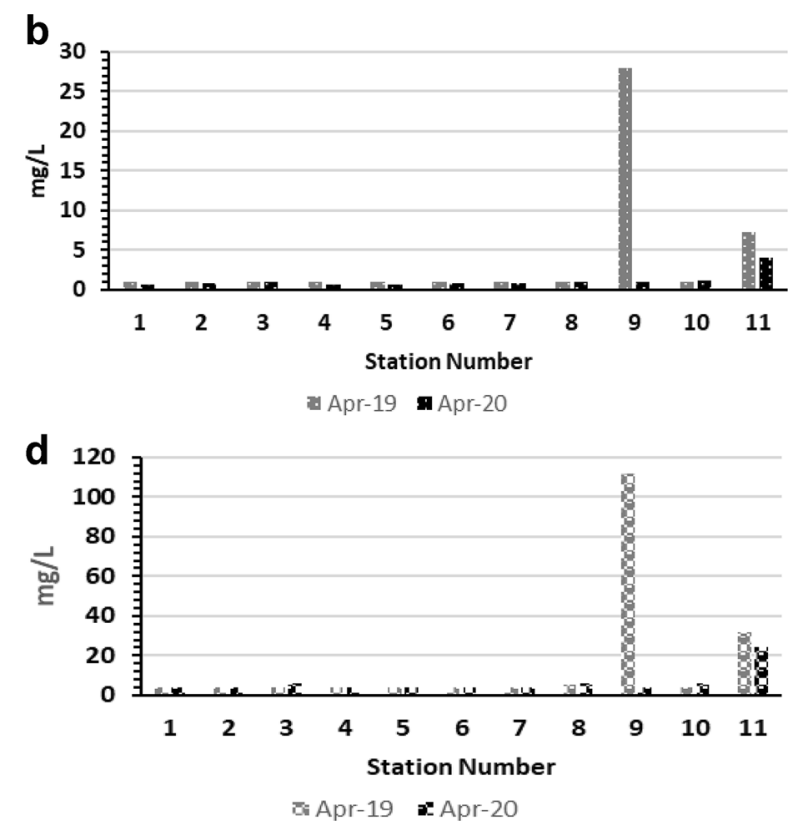

monthly averages comparison of BOD levels for 11 stations in Uttrakhand. d 2019 vs 2020 monthly averages comparison of COD levels for 11 stations in Uttrakhand 
up the policies for untreated wastewater. The media conglomerate delineated it as an unparalleled, swift redemption of the holy river that was unheard off in the preceding three to four decades Shukla, 2020; Ani, 2020). Achieving this markedly improved water quality, a few weeks of lockdown outshone what governmental regulation and polices undertook in decades. The Nizamuddin Bridge, a major effluent hotspot of the Yamuna River, observed enormous abatements in the BOD (90\%) and COD (82\%) levels (Arif et al., 2020). Nine sites recorded an improvement of $37 \%$ in water quality index during the lockdown period. In contrast to the pre-lockdown phase, the biological oxygen demand, fecal coliform and chemical oxygen demand de-escalated by $42.83 \%$, $40 \%$, and $39.25 \%$, respectively (Patel et al., 2020). The Yamuna, alias Ganges is the most polluted river worldwide and the largest tributary of river Ganga. Additionally, Yamuna's Secchi disk depth, marked a 42-year high (Katariya, 2020). The increasing depth could be a ventilator for marine flora. The TDS concentration in the Dwarka river significantly reduced from 2457 to $987 \mathrm{mg} / \mathrm{l}$ amidst the lockdown (Mandal $\&$ Pal, 2020). The marked improvements in the Beas waters resuscitated the Baes Conservation Reserve with one of the rarest mammals worldwide, the Indus river dolphins (Kumar, 2020). The pandemic has impelled a necessary rethink on the rejuvenation of Ganga waters and flagged some fundamental responses:

1. Redefining stringent regulations and enforcements for treatment and discharge of industrial wastewaters

2. Escalating the pace of the project implementation and exhaustive monitoring and assessment

3. Designing specific strategies for urban centers and hotspots

The swift improvements in water qualities in the urban centers enunciate the unequivocal attribution of anthropogenic activities and an opportunity to reflect.

\section{Conclusion}

The study includes the variations in the environmental pollutants (AQI, $\mathrm{NO}_{2}, \mathrm{SO}_{2}, \mathrm{PM}_{2.5}$, and $\mathrm{PM}_{10}$ ) in the lockdown period of the four major urban states of India. The findings emphasize that the anthropogenic halt during the lockdown period significantly reduced the concentrations of environmental pollutants in all the study states. Among selected pollutants, AQI, $\mathrm{NO}_{2}$, and $\mathrm{PM}_{2.5}$ demonstrated significant, postive corelations with COVID-19 mortality and infectivity. Furthermore, this investigation contributes towards a better comprehension in the contribution and role that restricted anthropogenic activities illustrate in the reduction of environmental pollutants, thereby, further addressing the speculations on the implementation of partial lockdowns to ensure healthy improved environmental characteristics. Consequently, aiding the establishment of a sustainable environment, inarguably, the most indispensable and paramount challenge of the twenty-first era.

Acknowledgements The authors would like to thank Aanandita Bhagat and Arshmeet Kaur Chawla for their constant support and motivation and Tanu Prakash for helping in the use of ArcGIS.

Author contribution MM collected data, analyzed, and prepared the manuscript draft; PKA conceived and designed the structure of the work. All authors read and approved the final version of the manuscript.

\section{Declarations}

Conflict of interest The authors declare no competing interests.

\section{References}

Achakulwisut, P., Brauer, M., Hystad, P., \& Anenberg, S. C. (2019). Global, national, and urban burdens of paediatric asthma incidence attributable to ambient NO 2 pollution: Estimates from global datasets. The Lancet Planetary Health, 3(4), e166-e178. https://doi.org/10.1016/S25425196(19)30046-4

Ani. (2020). Lockdown impact: Ganga water quality improves by 40-50 percent, says expert. The New Indian Express. Accessed May 25, 2020, from https://www.newindianexpress.com/ nation/2020/apr/05/lockdown-impact-ganga-water-qualityimproves-by-40-50-per-cent-says-expert-2126078.html

Arif, M., Kumar, R., \& Parveen, S. (2020). Reduction in water pollution in Yamuna River due to lockdown under COVID-19 pandemic. ChemRxiv. https://doi.org/10. 26434/chemrxiv.12440525.v1

Asensio, C., Pavón, I., \& de Arcas, G. (2020). Changes in noise levels in the city of Madrid during COVID-19 lockdown in 2020. The Journal of the Acoustical Society of 
America, 148(3), 1748-1755. https://doi.org/10.1121/10. 0002008

Ashenden, C. L., Lindsay, J. M., Sherburn, S., Smith, I. E. M., Miller, C. A., \& Malin, P. E. (2011). Some challenges of monitoring a potentially active volcanic field in a large urban area: Auckland volcanic field, New Zealand. Natural Hazards, 59(1), 507-528. https://doi.org/10.1007/ s11069-011-9773-0

Basu, B., Murphy, E., Molter, A., Sarkar Basu, A., Sannigrahi, S., Belmonte, M., \& Pilla, F. (2020). Investigating changes in noise pollution due to the COVID-19 lockdown: The case of Dublin. Ireland: Sustainable Cities and Society. https://doi.org/10.1016/j.scs.2020.102597

Bauwens, M., Compernolle, S., Stavrakou, T., Müller, J. F., van Gent, J., Eskes, H., Levelt, P. F., van der A, R., Veefkind, J. P., Vlietinck, J., Yu, H., \& Zehner, C. (2020). Impact of coronavirus outbreak on NO2 pollution assessed using TROPOMI and OMI observations. Geophysical Research Letters, 47(11), 1-9. https://doi.org/10.1029/2020GL087978

Bedi, J. S., Dhaka, P., Vijay, D., Aulakh, R. S., \& Gill, J. P. S. (2020). Assessment of air quality changes in the four metropolitan cities of india during COVID-19 pandemic lockdown. Aerosol and Air Quality Research, 20(10), 2062-2070. https://doi.org/10.4209/aaqr.2020.05.0209

Bernardini, F., Attademo, L., Trezzi, R., Gobbicchi, C., Balducci, P. M., Del Bello, V., et al. (2020). Air pollutants and a daily number of admissions to psychiatric emergency services: Evidence for detrimental mental health effects of ozone. Epidemiol Psychiatr Sci, 29, 66. https://doi.org/10.1017/ S2045796019000623

Bilal, Bashir, M. F., \& Benghoul, M. et al. (2020). Environmental pollution and COVID-19 outbreak: Insights from Germany. Air Quality, Atmosphere \& Health, 13, 1385-1394. https:// doi.org/10.1007/s11869-020-00893-9

Boese, C. M., Wotherspoon, L., Alvarez, M., \& Malin, P. (2015). Analysis of anthropogenic and natural noise from multilevel borehole seismometers in an urban environment, Auckland, New Zealand. Bulletin of the Seismological Society of America, 105(1), 285-299. https://doi. org/10.1785/0120130288

Brandt, E. B., Beck, A. F., \& Mersha, T. B. (2020). Air pollution, racial disparities, and COVID-19 mortality. Journal of Allergy and Clinical Immunology, 146(1), 61-63.

Brune, J. N., \& Oliver, J. (1959). The seismic noise of the earth's surface. Bulletin of the Seismological Society of America, 49(4), 349-353.

Castellanos, P., \& Boersma, K. F. (2012). Reductions in nitrogen oxides over Europe driven by environmental policy and economic recession. Scientific Reports, 2(2), 1-7. https://doi.org/10.1038/srep00265

Chan, J. F., \& Kok, K. (2020). Correction to: Genomic characterization of the 2019 novel human-pathogenic coronavirus isolated from a patient with atypical pneumonia after visiting Wuhan. Emerging Microbes and Infections, 9(1), 540. https://doi.org/10.1080/22221751.2020.1737364

Chan, J. F. W., Yuan, S., Kok, K. H., To, K. K. W., Chu, H., Yang, J., Xing, F., Liu, J., Yip, C. C. Y., Poon, R. W. S., Tsoi, H. W., Lo, S. K. F., Chan, K. H., Poon, V. K. M., Chan, W. M., Ip, J. D., Cai, J. P., Cheng, V. C. C., Chen, H., \& Yuen, K. Y. (2020). A familial cluster of pneumonia associated with the
2019 novel coronavirus indicating person-to-person transmission: A study of a family cluster. The Lancet, 395(10223), 514-523. https://doi.org/10.1016/ S0140-6736(20)30154-9

Chen, N., Zhou, M., Dong, X., Qu, J., Gong, F., Han, Y., Qiu, Y., Wang, J., Liu, Y., Wei, Y., Xia, J., Yu, T., Zhang, X., \& Zhang, L. (2020a). Epidemiological and clinical characteristics of 99 cases of 2019 novel coronavirus pneumonia in Wuhan, China: A descriptive study. The Lancet, 395(10223), 507-513. https://doi.org/10.1016/ S0140-6736(20)30211-7

Chen, W., Wang, Q., Li, Y. Q., Yu, H. L., Xia, Y. Y., Zhang, M. L., Qin, Y., Zhang, T., Peng, Z. B., Zhang, R. C., Yang, X. K., Yin, W. W., An, Z. J., Wu, D., Yin, Z. D., Li, S., Chen, Q. L., Feng, L. Z., Li, Z. J., \& Feng, Z. J. (2020b). Early containment strategies and core measures for prevention and control of novel coronavirus pneumonia in China. Zhonghua Yu Fang Yi Xue Za Zhi [chinese Journal of Preventive Medicine]. https://doi. org/10.3760/cma.j.issn.0253-9624.2020.03.003

Clark, C., \& Paunovic, K. (2018). Who environmental noise guidelines for the European region: A systematic review on environmental noise and quality of life, wellbeing and mental health. International Journal of Environmental Research and Public Health, 15(11). https:// doi.org/10.3390/ijerph15112400

Clark, C. W., Ellison, W. T., Southall, B. L., Hatch, L., Van Parijs, S. M., Frankel, A., \& Ponirakis, D. (2009). Acoustic masking in marine ecosystems : Intuitions, analysis, and implication. Marine Ecology Progress Series, 395, 201-222. https://doi.org/10.3354/meps08402

Coccia, M. (2020). Factors determining the diffusion of COVID-19 and suggested strategy to prevent future accelerated viral infectivity similar to COVID. Science of the Total Environment, 729, 138474. https://doi.org/10. 1016/j.scitotenv.2020.138474

Conticini, E., Frediani, B., \& Caro, D. (2020). Can atmospheric pollution be considered a co-factor in extremely high level of SARS-CoV-2 lethality in Northern Italy? Environmental Pollution, 261, 114465.

Dutta, V., Dubey, D., \& Kumar, S. (2020). Cleaning the River Ganga: Impact of lockdown on water quality and future implications on river rejuvenation strategies. Science of the Total Environment, 743, 140756. https://doi.org/10. 1016/j.scitotenv.2020.140756

El País. (2020). Coronavirus: El mapa del silencio en Madrid. Accessed April 12, 2020, from https://elpais.com/espana/ madrid/2020-04-11/madrid-alcanza-la-calidad-acusticarecomendada-por-la-oms.html

Faustini, A., Rapp, R., \& Forastiere, F. (2014). Nitrogen dioxide and mortality: Review and meta-analysis of long-term studies. European Respiratory Journal, 44(3), 744-753.

Francis, M. P. (2011). The economic impacts of inadequate sanitation in India. Water and sanitation program.

Gautam, S. (2020). The influence of COVID-19 on air quality in India: A boon or Inutile. Bulletin of Environmental Contamination and Toxicology, 104, 724-726. https:// doi.org/10.1007/s00128-020-02877-y

Ginzburg, A. S., Semenov, V. A., Semutnikova, E. G., Aleshina, M. A., Zakharova, P. V., \& Lezina, E. A. 
(2020). Impact of COVID-19 lockdown on air quality in Moscow. Doklady Earth Sciences, 495(1), 862-866. https://doi.org/10.1134/S1028334X20110069

Graham, R. L., Donaldson, E. F., \& Baric, R. S. (2013). A decade after SARS: Strategies for controlling emerging coronaviruses. Nature Reviews Microbiology, 11(12), 836-848. https://doi.org/10.1038/nrmicro3143

Guarnieri, M., \& Balmes, J. R. (2014). Outdoor air pollution and asthma. The Lancet, 383(9928), 1581-1592.

Heiberger, R. M., \& Holland, B. (2015). Data and Statistics. 13-27. https://doi.org/10.1007/978-1-4939-2122-5_2

Hui, D. S., Azhar, E. I., Kim, Y. J., Memish, Z. A., Oh, M. don, \& Zumla, A. (2018). Middle East respiratory syndrome coronavirus: risk factors and determinants of primary, household, and nosocomial transmission. The Lancet Infectious Diseases, 18(8), e217-e227. https:// doi.org/10.1016/S1473-3099(18)30127-0

Ibrar, M., \& Gandhiok, J. (2020). Covid-19: Noise pollution falls as lockdown rings in sound of silence. Times of India, 1-6. Accessed April 23, 2020, from https:// timesofindia.indiatimes.com/india/covid-19-noisepollution-falls-as-lockdown-rings-in-sound-of-silence/ articleshow/75309318.cms

IQAir. (2019). World air quality. 2019 World Air Quality Report, 1-22. Accessed March 18, 2020, from https:// www.iqair.com/world-most-polluted-cities/world-airquality-report-2019-en.pdf

Johnson, M. (2020). Wuhan 2019 novel coronavirus - 2019nCoV. Materials and Methods, 10, 1-5. https://doi.org/ 10.13070/mm.en.10.2867

Kamboj, N., \& Kamboj, V. (2019). Water quality assessment using overall index of pollution in riverbed-mining area of Ganga-River Haridwar, India. Water Science, 33(1), 65-74. https://doi.org/10.1080/11104929.2019.1626631

Kaplan, M. B., \& Solomon, S. (2016). A coming boom in commercial shipping? The potential for rapid growth of noise from commercial ships by 2030. Marine Policy, 73, 119-121. https://doi.org/10.1016/j.marpol.2016.07. 024

Katariya, M. (2020). 10 things that have happened for the first time in years during the coronavirus lockdown. ScoopWhoop. Accessed May 5, 2020, from https://www. scoopwhoop.com/news/things-that-have-happened-forthe-first-time-in-years-during-coronavirus-lockdown/

Kin, N., Miszczak, F., Lin, W., Gouilh, M. A., Vabret, A., Epicorem Consortium. (2015). Genomic analysis of 15 human coronaviruses OC43 (HCoV-OC43s) circulating in France from 2001 to 2013 reveals a high intra-specific diversity with new recombinant genotypes. Viruses, 7(5), 2358-2377. https://doi.org/10.3390/v7052358

Kissler, S. M., Tedijanto, C., Goldstein, E., Grad, Y. H., \& Lipsitch, M. (2020). Projecting the transmission dynamics of SARS-CoV-2 through the postpandemic period. Science, 368(6493), 860-868. https://doi.org/10.1126/ science.abb5793

Kumar, V. (2020). Punjab: With Beas pollution down , rare Indus river dolphins venturing out. Times of India. Accessed May, 5, from https://timesofindia.indiatimes. com/city/chandigarh/punjab-with-beas-pollution-downrare-indus-river-dolphins-venturing-out/articleshow/ 75567134.cms
Lai, S., Ruktanonchai, N. W., Zhou, L., Prosper, O., Luo, W., Floyd, J. R., Wesolowski, A., Santillana, M., Zhang, C., Du, X., Yu, H., \& Tatem, A. J. (2020). Effect of nonpharmaceutical interventions to contain COVID-19 in China. Nature, 585(7825), 410-413. https://doi.org/10. 1038/s41586-020-2293-x

Lau, H., Khosrawipour, V., Kocbach, P., Mikolajczyk, A., Schubert, J., Bania, J., \& Khosrawipour, T. (2020). The positive impact of lockdown in Wuhan on containing the COVID-19 outbreak in China. Journal of Travel Medicine, 27(3), 1-7. https://doi.org/10.1093/jtm/taaa037

Le Quéré, C., Jackson, R. B., Jones, M. W., Smith, A. J. P., Abernethy, S., Andrew, R. M., De-Gol, A. J., Willis, D. R., Shan, Y., Canadell, J. G., Friedlingstein, P., Creutzig, F., \& Peters, G. P. (2020). Temporary reduction in daily global $\mathrm{CO} 2$ emissions during the COVID-19 forced confinement. Nature Climate Change, 10(7), 647-653. https://doi.org/10. 1038/s41558-020-0797-x

Lecocq, T., Hicks, S. P., Noten, K. V., Wijk, K. V., \& Koelemeijer, P. (2020). Global quieting of high-frequency seismic noise due to COVID-19 pandemic lockdown measures. Science, 369(6509), 1338-1343. https://doi. org/10.1126/science.abd2438

Li, Q., Guan, X., Wu, P., Wang, X., Zhou, L., Tong, Y., Ren, R., Leung, K. S. M., Lau, E. H. Y., Wong, J. Y., Xing, X., Xiang, N., Wu, Y., Li, C., Chen, Q., Li, D., Liu, T., Zhao, J., Liu, M., \& Feng, Z. (2020). Early transmission dynamics in Wuhan, China, of novel coronavirus-infected pneumonia. New England Journal of Medicine, 382(13), 1199-1207. https://doi.org/10.1056/nejmoa2001316

Lindsey, N. J., Yuan, S., Lellouch, A., Gualtieri, L., Lecocq, T., \& Biondi, B. (2020). City-scale dark fiber DAS measurements of infrastructure use during the COVID19 pandemic. Geophysical Research Letters, 47(16), e2020GL089931. https://doi.org/10.1029/2020GL089931

Lu, H., Stratton, C. W., \& Tang, Y. W. (2020). Outbreak of pneumonia of unknown etiology in Wuhan, China: The mystery and the miracle. Journal of Medical Virology, 92(4), 401402. https://doi.org/10.1002/jmv.25678

Mallapaty, S. (2020). How sewage could reveal true scale of coronavirus outbreak. Nature, 580. April 20, 2020.

Mandal, I., \& Pal, S. (2020). COVID-19 pandemic persuaded lockdown effects on environment over stone quarrying and crushing areas. Science of the Total Environment, 732, 139281. https://doi.org/10.1016/j.scitotenv.2020.139281

Mccall, G. J. H., Way, R. F., \& Cerney, S. (1998). Geohazards and the urban environment. Geohazards in Engineering Geology, 1998, 309-318. https://doi.org/10.1144/GSL. ENG.1998.015.01.31

McNamara, D. E., \& Buland, R. P. (2004). Ambiente noise levels in the continental United States. Bulletin of the Seismological Society of America, 94(4), 1517-1527. https:// doi.org/10.1785/012003001

Minhas, A. S., MD., Scheel, P., MD., Garibaldi, B. MD., Liu, G., M.D., M.Sc., Horton, M., M.D., Jennings, M M.D., M.H.S., Jones, S. R., M.D., Michos, E. D., M.D., M.H.S., Hays, A. G., M. D. (2015). Middle East respiratory syndrome. Ann Oncol, January, 19-20.

Nowacek, D. P., Thorne, L. H., Johnston, D. W., \& Tyack, P. L. (2007). Responses of cetaceans to anthropogenic noise. 
Mammal Review, 37(2), 81-115. https://doi.org/10. 1111/j.1365-2907.2007.00104.x

Ogen, Y. (2020). Assessing nitrogen dioxide (NO2) levels as a contributing factor to coronavirus (COVID-19) fatality. Science of the Total Environment, 726, 138605. https:// doi.org/10.1016/j.scitotenv.2020.138605

Osborne, M. T., Radfar, A., Hassan, M. Z. O., Abohashem, S., Oberfeld, B., Patrich, T., Tung, B., Wang, Y., Ishai, A., Scott, J. A., Shin, L. M., Fayad, Z. A., Koenen, K. C., Rajagopalan, S., Pitman, R. K., \& Tawakol, A. (2020). A neurobiological mechanismlinking transportation noise to cardiovascular disease in humans. European Heart Journal, 41(6), 772-782. https://doi.org/10.1093/ eurheartj/ehz820

Patel, P. P., Mondal, S., \& Ghosh, K. G. (2020). Some respite for India's dirtiest river? Examining the Yamuna's water quality at Delhi during the COVID-19 lockdown period. Science of the Total Environment, 744, 140851. https:// doi.org/10.1016/j.scitotenv.2020.140851

Pepe, E., Bajardi, P., Gauvin, L., Privitera, F., Lake, B., Cattuto, C., \& Tizzoni, M. (2020). COVID-19 outbreak response, a dataset to assess mobility changes in Italy following national lockdown. Scientific Data, 7(1), 3-9. https://doi. org/10.1038/s41597-020-00575-2

Phosri, A., Ueda, K., Phung, V. L. H., Tawatsupa, B., Honda, A., \& Takano, H. (2019). Effects of ambient air pollution on daily hospital admissions for respiratory and cardiovascular diseases in Bangkok, Thailand. Science of the Total Environment, 651, 1144-1153. https://doi.org/10. 1016/j.scitotenv.2018.09.183

Poli, P., Boaga, J., Molinari, I., Cascone, V., \& Boschi, L. (2020). The 2020 coronavirus lockdown and seismic monitoring of anthropic activities in Northern Italy. Scientific Reports, 10(1), 1-8. https://doi.org/10.1038/s41598-020-66368-0

Pulla, P. (2020). COVID-19: India imposes lockdown for 21 days and cases rise. BMJ (clinical Research Ed.), 368, m1251. https://doi.org/10.1136/bmj.m1251

Ramanathan, K., Antognini, D., Combes, A., Paden, M., Zakhary, B., Ogino, M., Maclaren, G., \& Brodie, D. (2020). Clinical features of patients infected with 2019 novel coronavirus in Wuhan, China. The Lancet, 395, 497506. https://doi.org/10.1016/S0140-6736(20)30183-5This

Riou, J., \& Althaus, C. L. (2020). Pattern of early human-to-human transmission of Wuhan 2019 novel coronavirus (2019-nCoV), December 2019 to January 2020. Eurosurveillance, 25(4), 1-5. https://doi.org/10.2807/1560-7917.ES.2020.25.4.2000058

Rolland, R. M., Parks, S. E., Hunt, K. E., Castellote, M., Corkeron, P. J., Douglas, P., Wasser, S. K., \& Kraus, S. D. (2012). Evidence that ship noise increases stress in right whales. Proceedings of the Royal Society B: Biological Sciences, 279(1737), 2363-2368. https://doi.org/10.1098/rspb.2011.2429

Ross, Z. E., Trugman, D. T., Hauksson, E., \& Shearer, P. M. (2019). Searching for hidden earthquakes in Southern California. Science, 771, 767-771. https://doi.org/10.1126/ science.aaw6888

Rutz, C., Loretto, M. C., Bates, A. E., Davidson, S. C., Duarte, C. M., Jetz, W., Johnson, M., Kato, A., Kays, R., Mueller, T., Primack, R. B., Ropert-Coudert, Y., Tucker, M. A., Wikelski, M., \& Cagnacci, F. (2020). COVID-19 lockdown allows researchers to quantify the effects of human activity on wildlife. Nature Ecology and Evolution, 4(9), 1156-1159. https://doi.org/10.1038/s41559-020-1237-z

Schuman, B. R. (2020). National traffic volume synopsis : Issue \# 3 (March 28-April 3, 2020). INRIX U.S. Accessed April 6, 2020, from https://inrix.com/blog/ 2020/04/covid19-us-traffic-volume-synopsis-3/\#_ftn1

Setti, L., Passarini, F., de Gennaro, G., Barbieri, P., Perrone, M. G., Piazzalunga, A., et al. (2020). The potential role of particulate matter in the spreading of COVID-19 in Northern Italy: First evidence-based research hypotheses. medRxiv. https://doi.org/10.1101/2020.04.11.20061713

Shakoor, A., Chen, X., Farooq, T. H., et al. (2020). Fluctuations in environmental pollutants and air quality during the lockdown in the USA and China: Two sides of COVID-19 pandemic. Air Quality, Atmosphere and Health, 13, 13351342. https://doi.org/10.1007/s11869-020-00888-6

Sharma, S., Zhang, M., Gao, J., Zhang, H., \& Kota, S. H. (2020). Effect of restricted emissions during COVID-19 on air quality in India. Science of the Total Environment, $728,138878$.

Shen, M., Peng, Z., Guo, Y., Rong, L., Li, Y., Xiao, Y., Zhuang, G., \& Zhang, L. (2020). Assessing the effects of metropolitan-wide quarantine on the spread of COVID-19 in public space and households. International Journal of Infectious Diseases, 96, 503-505. https://doi.org/10. 1016/j.ijid.2020.05.019

Shukla, H. (2020). Lockdown impact: Ganga water in Haridwar becomes "fit to drink" after decades - India News. https:// www.indiatoday.in/india/story/lockdown-impact-gangawater-in-haridwar-becomes-fit-to-drink-after-decades1669576-2020-04-22

Singhal, (2020). COVID-19 lockdown: A ventilator for rivers. DownToEarth. April 29, 2020, from https://www.downtoearth. org.in/blog/covid-19-lockdown-a-ventilator-for-rivers-70771

Smith, L. M., Wang, L., Mazur, K., Carchia, M., DePalma, G., Azimi, R., \& Neitzel, R. L. (2020). Impacts of COVID19-related social distancing measures on personal environmental sound exposures. Environmental Research Letters, 15(10), 104094. https://doi.org/10.1088/17489326/abb494

Sohrabi, C., Alsafi, Z., O’Neill, N., Khan, M., Kerwan, A., AlJabir, A., Iosifidis, C., \& Agha, R. (2020). World Health Organization declares global emergency: A review of the 2019 novel coronavirus (COVID-19). International Journal of Surgery, 76(February), 71-76. https://doi.org/10. 1016/j.ijsu.2020.02.034

Song, Z., Xu, Y., Bao, L., Zhang, L., Yu, P., Qu, Y., Zhu, H., Zhao, W., Han, Y., \& Qin, C. (2019). From SARS to MERS, thrusting coronaviruses into the spotlight. Viruses. https:// doi.org/10.3390/v11010059

Su, S., Wong, G., Liu, Y., Gao, G. F., Li, S., \& Bi, Y. (2015). MERS in South Korea and China: A potential outbreak threat? In The Lancet (Vol. 385, Issue 9985, pp. 23492350). Lancet Publishing Group. https://doi.org/10.1016/ S0140-6736(15)60859-5

Su, S., Wong, G., Shi, W., Liu, J., Lai, A. C. K., Zhou, J., Liu, W., Bi, Y., \& Gao, G. F. (2016). Epidemiology, genetic recombination, and pathogenesis of coronaviruses. Trends in Microbiology, 24(6), 490-502. https://doi.org/10. 1016/j.tim.2016.03.003 
Strak, M., Janssen, N., Beelen, R., Schmitz, O., Vaartjes, I., Karssenberg, D., \& Hoek, G. (2017). Long-term exposure to particulate matter, $\mathrm{NO} 2$ and the oxidative potential of particulates and diabetes prevalence in a large national health survey. Environment International, 108, 228-236. https://doi.org/10.1016/j.envint.2017.08.017

Thomson, D. J. M., \& Barclay, D. R. (2020). Real-time observations of the impact of COVID-19 on underwater noise. The Journal of the Acoustical Society of America, 147(5), 3390-3396. https://doi.org/10.1121/10.0001271

Travaglio, M., Yu, Y., Popovic, R., Selley, L., Leal, N. S., \& Martins, L. M. (2021). Links between air pollution and COVID-19 in England. Environmental Pollution, 268, 115859.

Trivedi, R. C. (2010). Water quality of the Ganga River - an overview. Aquatic Ecosystem Health and Management, 13(4), 347-351. https://doi.org/10.1080/14634988.2010.528740

Tyack, P. L. (2008). Implications for marine mammals of largescale changes in the marine acoustic environment. Journal of Mammalogy, 89(3), 549-558. https://doi.org/10.1644/ 07-MAMM-S-307R.1

UNICEF. (2006). Report card on water and sanitation. Progress for Children, 5.

United Nations Environment Programme. (2019). Emissions gap report 2019. In Emissions Gap Report 2019.

Vadrevu, K. P., Eaturu, A., Biswas, S., Lasko, K., Sahu, S., Garg, J. K., \& Justice, C. (2020). Spatial and temporal variations of air pollution over 41 cities of India during the COVID-19 lockdown period. Scientific Reports, 10(1), 1-15. https://doi. org/10.1038/s41598-020-72271-5

van Kempen, E., Casas, M., Pershagen, G., \& Foraster, M. (2018). WHO environmental noise guidelines for the European region: A systematic review on environmental noise and cardiovascular and metabolic effects: A summary. International Journal of Environmental Research and Public Health, 15(2), 1-59. https://doi.org/10.3390/ijerph15020379

Verity, R., Okell, L. C., Dorigatti, I., Winskill, P., Whittaker, C., Imai, N., \& Ferguson, N. M. (2020). Estimates of the severity of coronavirus disease 2019: A model-based analysis. The Lancet Infectious Diseases, 20(6), 669-677.

Weiss, S. R., \& Navas-Martin, S. (2005). Coronavirus pathogenesis and the emerging pathogen severe acute respiratory syndrome coronavirus. Microbiology and Molecular Biology Reviews, 69(4), 635-664. https://doi.org/ 10.1128/mmbr.69.4.635-664.2005

World Health Organization. (2020)! Estimating mortality from COVID-19: scientific brief, August, 4. World Health Organization. https://apps.who.int/iris/handle/ 10665/333642. License: CC BY-NC-SA 3.0 IGO

Wigley, T. M. L., Jones, P. D., \& Kelly, P. M. (1981). Global warming? Nature, 291(5813), 285. https://doi.org/10. 1038/291285a0

World Bank. (2013). India: Diagnostic assessment of select environmental challenges. An Analysis of Physical and Monetary Losses of Environmental Health and Natural Resources, I(70004). http://www-wds.worldbank.org/ external/default/WDSContentServer/WDSP/IB/2013/ 07/16/000442464_20130716091943/Rendered/PDF/ 700040v10ESW0P0box0374379B00PUBLIC0.pdf
World Health Organization. (2018). 9 Out of 10 people worldwide breathe polluted air. World Heath Organization (WHO). Accessed May 2, 2020, from https:// www. who.int/news/item/02-05-2018-9-out-of-10people-worldwide-breathe-polluted-air-but-morecountries-are-taking-action.

World Health Organization. (2019). Ten threats to global health in 2019. World Health Organisation (WHO), March, 1-18. https://www.who.int/emergencies/tenthreats-to-global-health-in-2019.

The World Health Organization (WHO). (2020a). Pneumonia of unknown cause - China. In Disease outbreak news. World Health Organization (WHO). Accessed January 5, 2020, from https://www.who.int/csr/don/05-january-2020pneumonia-of-unkown-cause-china/en/\#.X51d50I6zw4. mendeley

World Health Organization. (2020b). WHO I novel coronavirus - China. Disease Outbreak News: Update; World Health Organization (WHO). Accessed January 12, 2020, from https://www.who.int/csr/don/12-january-2020-novelcoronavirus-china/en/\#.X5lhdgjZuSO.mendeley

World Health Organization. (2020c). Weekly epidemiological update on COVID-19. World Health Organization (WHO). Accessed October 11, 2020, from https://www.who.int/docs/ default-source/coronaviruse/situation-reports/20201012weekly-epi-update-9.pdf

Wu, X., Nethery, R. C., Sabath, M. B., Braun, D., \& Dominici, F. (2020). Air pollution and COVID-19 mortality in the United States: Strengths and limitations of an ecological regression analysis. Science Advances, 6(45), 1-7. https:// doi.org/10.1126/SCIADV.ABD4049

Xiantian, X., Ping, C., Jingfang, W., Jiannan, F., Hui, Z., Xuan, L., Wu, Z., \& Pei, H. (2020). Evolution of the novel coronavirus from the ongoing Wuhan outbreak and modeling of its spike protein for risk of human transmission. Science China Life Sciences, 63(3), 457-460. https://doi.org/10. 1007/s11427-020-1637-5

Xiao, H., Eilon, Z. C., Ji, C., \& Tanimoto, T. (2020). COVID-19 societal response captured by seismic noise in China and Italy. Seismological Society of America, 91(5), 2757-2768. https://doi.org/10.1785/0220200147

Zhou, P., Yang, X. L., Wang, X. G., Hu, B., Zhang, L., Zhang, W., Si, H. R., Zhu, Y., Li, B., Huang, C. L., Chen, H. D., Chen, J., Luo, Y., Guo, H., Jiang, R. D., Liu, M. Q., Chen, Y., Shen, X. R., Wang, X., \& Shi, Z. L. (2020). A pneumonia outbreak associated with a new coronavirus of probable bat origin. Nature, 579(7798), 270-273. https://doi.org/10. 1038/s41586-020-2012-7

Zumla, A., Hui, D. S., \& Perlman, S. (2015). Middle East respiratory syndrome. The Lancet, 386(9997), 995-1007. https:// doi.org/10.1016/S0140-6736(15)60454-8

Publisher's Note Springer Nature remains neutral with regard to jurisdictional claims in published maps and institutional affiliations. 